\title{
Analysis and Design of Modules to Generate Students' Mathematical Communication Skills through Problem Based Learning Models
}

\author{
Agung Hendra Setiawan", Suparman ${ }^{1, *}$, Agus Suhendar², Tedy Machmud ${ }^{3}$, Sukardi Abbas $^{4}$, \\ Pamuti $^{5}$ \\ ${ }^{1}$ Postgraduate Program in Mathematics Education, Faculty of Teacher Training and Education, Universitas Ahmad Dahlan, Yogyakarta, \\ Indonesia \\ ${ }^{2}$ Faculty of Information Technology and Electrical Engineering, Universitas Teknologi Yogyakarta, Indonesia \\ ${ }^{3}$ Faculty of Mathematics and Science, Universitas Negeri Gorontalo, Indonesia \\ ${ }^{4}$ Faculty of Tarbiyah and Teacher Training, Institut Agama Islam Negeri Ternate, Indonesia \\ ${ }^{5}$ Faculty of Teacher Training and Education, Universitas Khairun, Ternate, Indonesia
}

Received September 3, 2020; Revised November 16, 2020; Accepted December 11, 2020

\section{Cite This Paper in the following Citation Styles}

(a): [1] Agung Hendra Setiawan, Suparman, Agus Suhendar, Tedy Machmud, Sukardi Abbas, Pamuti, "Analysis and Design of Modules to Generate Students' Mathematical Communication Skills through Problem Based Learning Models," Universal Journal of Educational Research, Vol. 8, No. 12A, pp. 7572 - 7582, 2020. DOI: 10.13189/ujer.2020.082543.

(b): Agung Hendra Setiawan, Suparman, Agus Suhendar, Tedy Machmud, Sukardi Abbas, Pamuti (2020). Analysis and Design of Modules to Generate Students' Mathematical Communication Skills through Problem Based Learning Models. Universal Journal of Educational Research, 8(12A), 7572 - 7582. DOI: 10.13189/ujer.2020.082543.

Copyright $\odot 2020$ by authors, all rights reserved. Authors agree that this article remains permanently open access under the terms of the Creative Commons Attribution License 4.0 International License

\begin{abstract}
The ability of mathematical communication is the ability of students to express mathematical ideas both oral and written in the form of language, symbols, and mathematical notations that are easier for students to understand mathematical problems. Problem based learning is a learning model that can be used to improve students' mathematical communication. In implementing the Problem Based Learning (PBL) model, teachers need appropriate modules. This study analyzes and designs teaching materials in the form of modules, based on the Problem Based Learning approach, allowing improving mathematical communication skills. The subjects of this study were students of class XI SMK Muhammadiyah 1 Sentolo, Kulonprogo. This type of research is research and development with the ADDIE development model. The collection instruments used were interview guides, classroom observations, and tests. Data analysis uses data reduction, data presentation, and drawing conclusions. This research produces an module needs analysis and module design according to the needs analysis. Modules are designed according to Problem Based Learning (PBL). Modules are designed to improve students' mathematical
\end{abstract}

communication skills. The results of the study can be used as a guide when the teacher develops a learning module for a problem-based learning model. The novelty of this research is the integration of mathematical communication skills into module design.

Keywords Mathematical Communication, Problem Based Learning, Modules Design

\section{Introduction}

Mathematical communication is the ability of students to express ideas in mathematics both oral and written in the form of language, symbols, and mathematical notations that are easier for students to understand mathematical problems [1]. According to the National Council of Teachers of Mathematics (NCTM) and Wahyudin, mathematical communication is the ability to reflect real objects, images or mathematical ideas; deliver orally, in writing, using real objects, graphics, and algebra; use the 
ability to read, write and analyze to translate and interpret mathematical ideas, symbols, terms, and information; and answer various problems of mathematical ideas [2]. Mathematical communication can be interpreted as the ability of students to convey something that students know through dialogue or reciprocal events that occur in the classroom environment, where there is a transfer of messages, where the message transferred contains mathematical material being studied, such as concepts, formulas, or solving strategies problem [3].

Mathematical communication has two important roles, namely: mathematics is a fundamental language that is not only a tool for thinking, solving problems, or concluding but also has limited value for expressing various ideas clearly, thoroughly and precisely; and learning mathematics is part of human social activities, as in learning there is the interaction between students and teachers [4]. Mathematical communication is the main key of students in creating mathematical concepts and strategies and to explore scientific inquiry which includes finding, exchanging opinions, assessing, and honing ideas to convince others [5]. Communication skills are used to determine whether a student understands the material being taught [6].

Based on the results of the 2018 International for Student Assessment Program (PISA), the average score of mathematics literacy scores, Indonesia ranked 76 out of 79 participating countries [7]. Communication skills are part of the aspects assessed in PISA [8]. This also happened at Vocational High School Muhammadiyah 1 Sentolo, Kulonprogo, in the 2019/2020 academic year. Based on interviews and observations it was found that learning resources/media are difficult for students to understand because the sentences are too formal and the learning model used is monotonous and conventional. Some of these, become one of the causes of the lack of students' mathematical communication skills.

Several studies have conducted research related to mathematical communication skills. The results of research conducted by Atika, Roza, and Murni (2020) show that the use of Problem Based Learning (PBL) can improve students' mathematical communication skills [9]. Similar research by Rahmantiwi and Rosnawati (2018) results in mathematical communication skills being improved through Problem Based Learning (PBL)[10]. And according to Sitopu, Saragih and Hasratuddin (2019) on the results of their research concluded that there is an influence of the Problem Based Learning (PBL) learning model on improving mathematical communication skills [11].

Problem Based Learning (PBL) model is a learning strategy that encourages students to be active and become confident in learning, and the Problem Based Learning (PBL) strategy model can encourage active students so that they can improve students' mathematical communication skills [12]. Problem Based Learning (PBL) is one of the learning models that is suitable for active learning and independent learning [13]. Problem-Based Learning (PBL) can make learning mathematics more effective and innovative because students tend to focus on their interests and talents and are more active in the learning process [14]. Problem Based Learning (PBL) which can improve learning, students who experience difficulties in learning [15]. Problem Based Learning (PBL) can help the students to find learning problems withing planning and problem solving [16]. The Problem Based Learning (PBL) approach is effective in preparing students for their future learning [17]. One solution to learning, mathematics learning must be accompanied by the use of teaching materials [6]. Teaching material with the right learning approach will support learning objectives [18]. Teaching materials in the form of modules can be considered as one of the right reasons [19]. Modules are teaching materials that are arranged systematically and are easily mastered by students according to their level of understanding and age so that they can learn independently with minimal assistance from the teacher [20].

Based on the problems and previous research results above, then to improve mathematical communication skills, the authors provide solutions to use modules based on Problem Based Learning (PBL). The purpose of this study is the analysis and design of modules to generate students' mathematical communication skills through the Problem Based Learning (PBL) model.

\section{Materials and Methods}

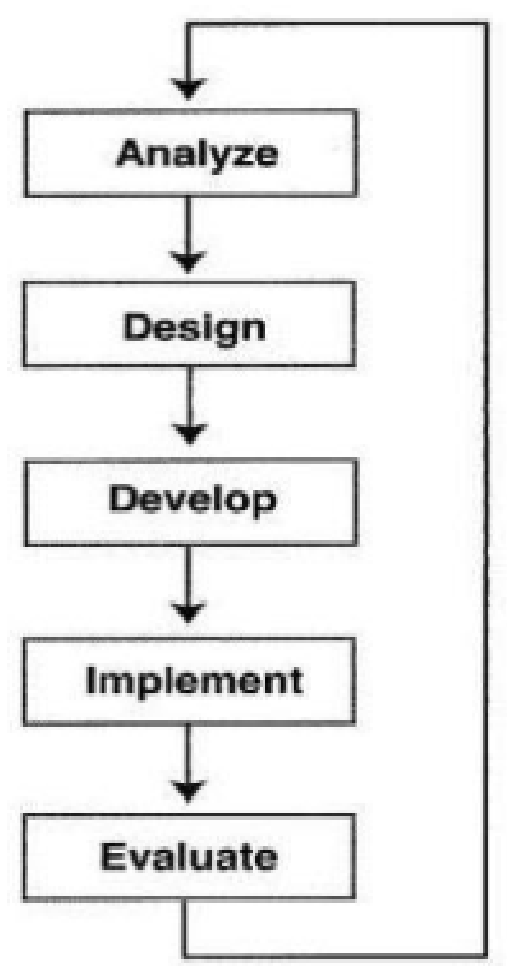

Figure 1. Development Process 
This study uses the ADDIE model. ADDIE is a research model that consists of several stages, namely: analysis, design, development, implementation, and evaluation [21], [22], [23]. Visually the ADDIE stages can be seen in Figure 1.

In this study, the authors limit to two stages, namely: the stages of analysis and design. The resulting product is a Problem Based Learning (PBL) based module designed to improve mathematical communication.

The analysis phase consists of curriculum analysis, material, student characteristics, and student achievement. While the research design stage is carried out through a framework of preparatory activities in the media and design of media learning. Products in the form of instructional media design are validated by experts. Design validation is carried out to determine the assessment and input from experts as a revision material so that the design of the development of good quality learning media.

Research subjects were all students of class XI semester 1 (one) Vocational High School Muhammadiyah 1 Sentolo, Kulonprogo, in the academic year 2019/2020. The type of data used is qualitative and quantitative. Data collection instruments include interview guides and classroom observations. Interview guidelines are used to interview teachers or students about the use of teaching materials used in the learning process, while the classroom observation guidelines are used to observe or know learning models that can improve students' mathematical communication skills. Data were analyzed using Huberman's Miles consisting of data reduction, data presentation, and conclusion drawing [24].

This research was conducted by designing problem-based learning in the XI grade mathematics learning module at Vocational High School Muhammadiyah 1 Sentolo, Kulonprogo. The following are the results of design development through the analysis phase and the ADDIE design phase.

\subsection{Final Stage}

\subsubsection{Curriculum Analysis}

Based on observations of the curriculum used in the learning material book by students following the Core Competencies, Basic Competencies, and Indicators of Achievement of Competencies in the 2013 curriculum. Whereas in the learning process it still uses conventional means that the teacher becomes the center of learning activities. The following are Core Competencies, Basic Competencies, and Indicators of Competency Achievement in Table 1 and Table 2.

Table 1. Core Competencies

\begin{tabular}{|c|c|}
\hline No & Core Competencies \\
\hline 1 & $\begin{array}{l}\text { Respect and appreciate the teachings of the religion they } \\
\text { hold }\end{array}$ \\
\hline 2 & $\begin{array}{l}\text { Appriciate and appreciate honest behavior, discipline, } \\
\text { responsibility, care (tolerance, cooperation), polite, } \\
\text { confident, in interacting effectively with the social and } \\
\text { natural environment within the reach of relationships and } \\
\text { their existence }\end{array}$ \\
\hline 3 & $\begin{array}{l}\text { Understanding knowledge (factual, conceptual, and } \\
\text { procedural) based on curiosity about science, technology, } \\
\text { art, culture related to phenomena and events seen in the eye }\end{array}$ \\
\hline 4 & $\begin{array}{l}\text { Trying, processing, and presenting in the real of concrete } \\
\text { (using, unraveling, composing, modifying, and making) as } \\
\text { well as abstract domains (writing, reading, calculating, } \\
\text { drawing, composing) following what is learned in school } \\
\text { and other sources in the sama perspective/theory. }\end{array}$ \\
\hline
\end{tabular}

Table 2. Basic Competencies and Competency Achievement Indicators

\begin{tabular}{|c|c|c|}
\hline Basic Competencies & Indicators of Competency Achievement & Information \\
\hline $\begin{array}{c}\text { 3.6 Explain the composition } \\
\text { operations on functions and } \\
\text { inverse operations on inverse } \\
\text { functions and their properties and } \\
\text { determine their existence }\end{array}$ & $\begin{array}{c}\text { 3.6.1 Explain the concept on function } \\
\text { 3.6.2 Explain operations on function } \\
\text { 3.6.3 Explain composition operations on function } \\
\text { 3.6.4 Explain the operating properties of compositions on function } \\
\text { 3.6.5 Explains the inverse operatin on the inverse function } \\
\text { 3.6.6 Explain the properties of inverse operations on the inverse function } \\
\text { 3.6.7 Determine the existence of an inverse operation on an inverse function }\end{array}$ & $\begin{array}{l}\text { Support } \\
\text { Key } \\
\text { Key } \\
\text { Key } \\
\text { Key } \\
\text { Key } \\
\text { Key }\end{array}$ \\
\hline $\begin{array}{l}\text { 4.6 Solve problems related to } \\
\text { composition operations and } \\
\text { inverse operations of a function }\end{array}$ & $\begin{array}{l}\text { 4.6.1 Express ideas related to contextual problems related to the function } \\
\text { 4.6.2 Resolve problems related to operating composition functions } \\
\text { 4.6.3 Resolve problems related to the inverse operations of a function }\end{array}$ & $\begin{array}{l}\text { Support } \\
\text { Key } \\
\text { Key }\end{array}$ \\
\hline
\end{tabular}




\subsubsection{Material Analysis}

Based on observations of the material contained in the learning tool used is less efficient, because it uses sentences or formal mathematical language. Also, teaching materials are not following the demands of $21 \mathrm{st}$ century learning to achieve the Basic Competencies to be achieved and do not meet the indicators of mathematical communication skills.

Students experience boredom in monotonous teaching materials, so students are less interested in studying teaching materials and do not understand the real flow of the material being taught. Some students only memorize the material or formula given by the teacher without knowing the process of the formula obtained, so there are often mistakes in applying the formula to solve problems. Thus, the flow of real activities needs to be developed chronologically so students can understand the material and objectives of learning. So students need modules that can help students improve mathematical communication.

\subsubsection{Analysis of Student Characteristics}

Students cannot understand the material well, resulting in a student's difficulty in working on problems that mostly come from everyday life. Based on interviews with Mr. Fachrul Rozi as a mathematics teacher in class XI mentioned the lack of mathematical communication skills of students of Vocational High School Muhammadiyah Sentolo, among the reasons for making students unable to understand mathematics well, students need modules that can help students understand the concept of the material well.

\subsubsection{Analysis of Learning Achievement}

Based on the results of interviews with teachers, it also obtained information that the lack of mathematical communication skills in students seen by the low learning achievement that is less than expected. This can all be seen in the mathematics test scores of students who have not yet reached the individual Minimum completeness Criteria of 70, so teachers must take remedial exams. Also, students can not be maximized in doing the tasks given, because learning tools do not support to understand the material provided, so we need learning tools that can support learning well.

Based on the above analysis, the researcher concludes that students and teachers need learning media in the form of modules that can help students improve mathematical communication skills so that the teaching and learning process is more effective and efficient.

\subsection{Design Phase}

In the design phase, the module will be designed in the form of Problem Based Learning (PBL) based mathematics learning modules to improve the mathematical communication skills of students in class XI of Vocational High School Muhammadiyah 1 Sentolo, Kulon Progo. Based on the description above, the module design has been made as follows.

\subsubsection{Opening Section}

\subsubsection{Cover}

The cover of the mathematics learning module based on Problem Based Learning (PBL) is entitled "Modul Pembelajaran Matematika Komposisi dan Invers Fungsi Berbasis Problem Based Learning (PBL) untuk Meningkatkan Kemampuan Siswa Kelas XI SMK". The cover is completed by the author's name, the origin of the university, and the subject matter contained in this module. Following is the module cover design in Figure 2 


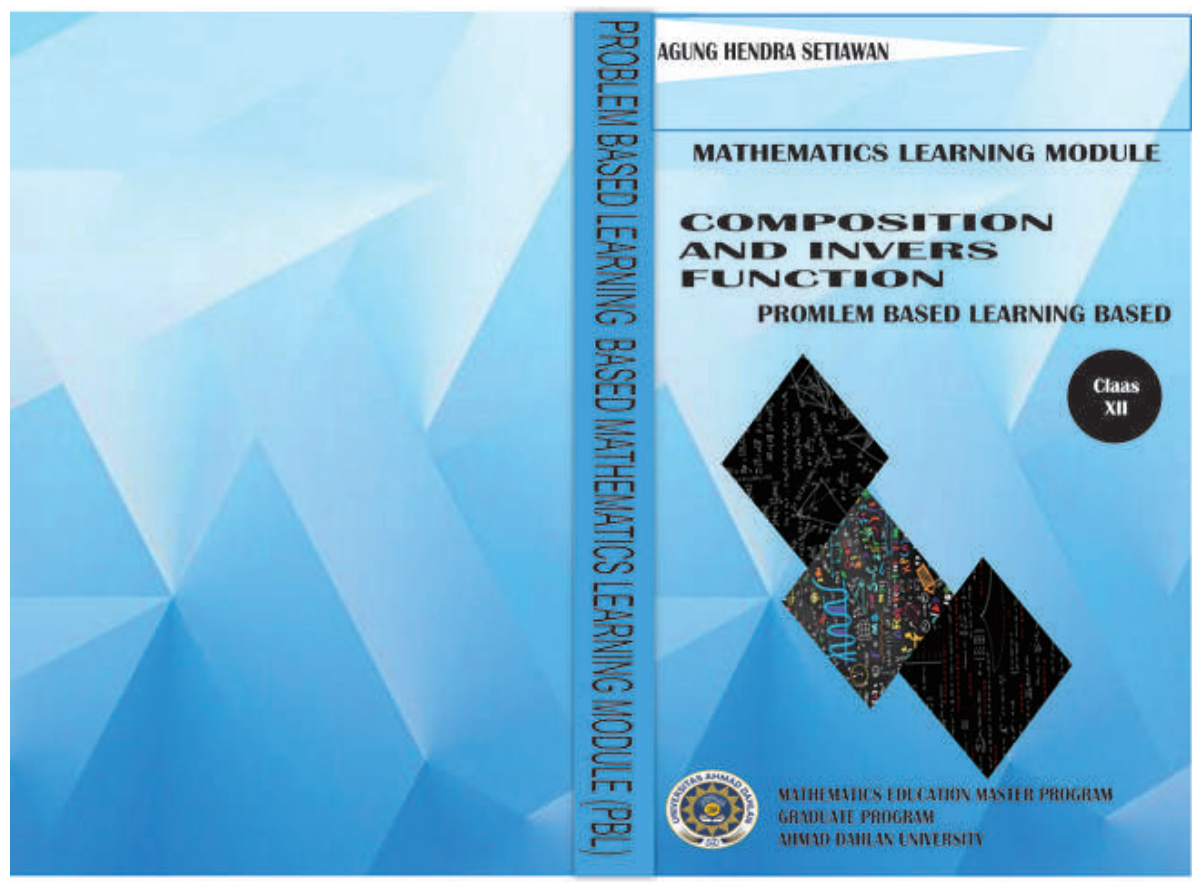

Figure 2. Display Cover

2.2.1.1. Foreword

\section{FOREWORD}

\section{Alhamdulillah}

Praise the presence of Allah Subhana wa Ta'ala for the abundance of mercy and grace from Him, we can complete this Problem Based Learning-based mathematics learning module. Prayers and greetings may always be poured out to our great lord, Prophet Muhammad Sallahu Alaihi wa Sallam who has shown us all the straight paths in the form of the perfect teachings of the Islamic religion and become the greatest gift to the entire universe.

The author is very grateful for completing the module with the material "Composition and Inverse Function". Besides that, we would like to thank all those who have helped you during the making of this mockery so that this paper can be realized.

That is what we can convey, I hope this module can be useful for readers. We expect criticism and suggestions for this paper so that in the future we can improve it. Because we are aware, there are still many shortcomings in this paper that we have written

Yogyakarta, Mei 2020

Agung Hendra Setiawan

Figure 3. Display Preface 
The introduction in the Problem Based Learning (PBL) module expresses gratitude to Allah Ta'ala and to those who have helped in the formation of this module and their apologies and suggestions. The following is the preface design that was created in Figure 3.

\subsubsection{List of Competency Objectives}

List of competency objectives in the Problem Based Learning (PBL) module contains what knowledge, attitudes, or skills can be mastered after completing learning. The following is a list of the designs of Core Competencies and Basic Competencies that have been created in Figure 4.

\section{CORE COMPETITION}

\begin{tabular}{|c|c|}
\hline No & Core Competencies \\
\hline 1 & Appreciate and live up to the teachings of his religion \\
\hline 2 & $\begin{array}{l}\text { Appreciate and live honest behavior, discipline, responsibility, care } \\
\text { (tolerance, mutual cooperation), courteous, self-confidence, in interacting } \\
\text { effectively with the social and natural environment within the range of } \\
\text { association and existence }\end{array}$ \\
\hline 3 & $\begin{array}{l}\text { Understand knowledge (factual, conceptual, and procedural) based on his } \\
\text { curiosity about science, technology, art, culture related to visible } \\
\text { phenomena and events. }\end{array}$ \\
\hline 4 & $\begin{array}{l}\text { Trying, processing, and presenting in the realm of the concrete (using, } \\
\text { unraveling, arranging, modifying, and making) as well as the abstract realm } \\
\text { (writing, reading, counting, drawing, and composing) according to what is } \\
\text { learned in school and other sources in the same perspective / theory. }\end{array}$ \\
\hline
\end{tabular}

\section{BASIC COMPETENCIES}

INDICATORS OF COMPEIENCE ACHIEVEMENT

\begin{tabular}{|c|c|c|}
\hline $\begin{array}{l}\text { Basic competencies } \\
\text { (BC) }\end{array}$ & $\begin{array}{l}\text { Indicators of Competence Achievement } \\
\text { (ICA) }\end{array}$ & Information| \\
\hline $\begin{array}{l}\text { 3.6Describecomposition } \\
\text { operations on functions } \\
\text { and inverse operations } \\
\text { on inverse functions and } \\
\text { their properties and } \\
\text { determine their } \\
\text { existence }\end{array}$ & $\begin{array}{l}\text { 3.6.1 Explain the concept of function } \\
3.6 .2 \text { Describe the operation on the } \\
\text { function } \\
\text { 3.6.3 Describe the composition operation } \\
\text { on the function } \\
\text { 3.6.4 Describe the operating properties of } \\
\text { the composition on the function } \\
\text { 3.6.5 Describe the inverse operation on the } \\
\text { inverse function } \\
\text { 3.6.6 Describe the properties of an inverse } \\
\text { operation on an inverse function } \\
3.6 .7 \text { Determine the existence of an } \\
\text { inverse operation on an inverse function }\end{array}$ & $\begin{array}{l}\text { Key } \\
\text { Key } \\
\text { Key }\end{array}$ \\
\hline $\begin{array}{l}4.6 \text { Solving problems } \\
\text { related to composition } \\
\text { operations and inverse } \\
\text { operations of a function. }\end{array}$ & $\begin{array}{l}4.6 .1 \text { Suggest ideas related to contextual } \\
\text { problems related to the functions of the } \\
\text { Two-Variable Linear. Equation System } \\
\text { (SPLDV) } \\
4.6 .2 \text { Solving problems related to the } \\
\text { function composition operation } \\
4,6,3 \text { Solve problems related to the inverse } \\
\text { operation of a functio }\end{array}$ & $\begin{array}{c}\text { Supporters } \\
\text { Key } \\
\text { Key }\end{array}$ \\
\hline
\end{tabular}




\section{CONCEPT MAPS}

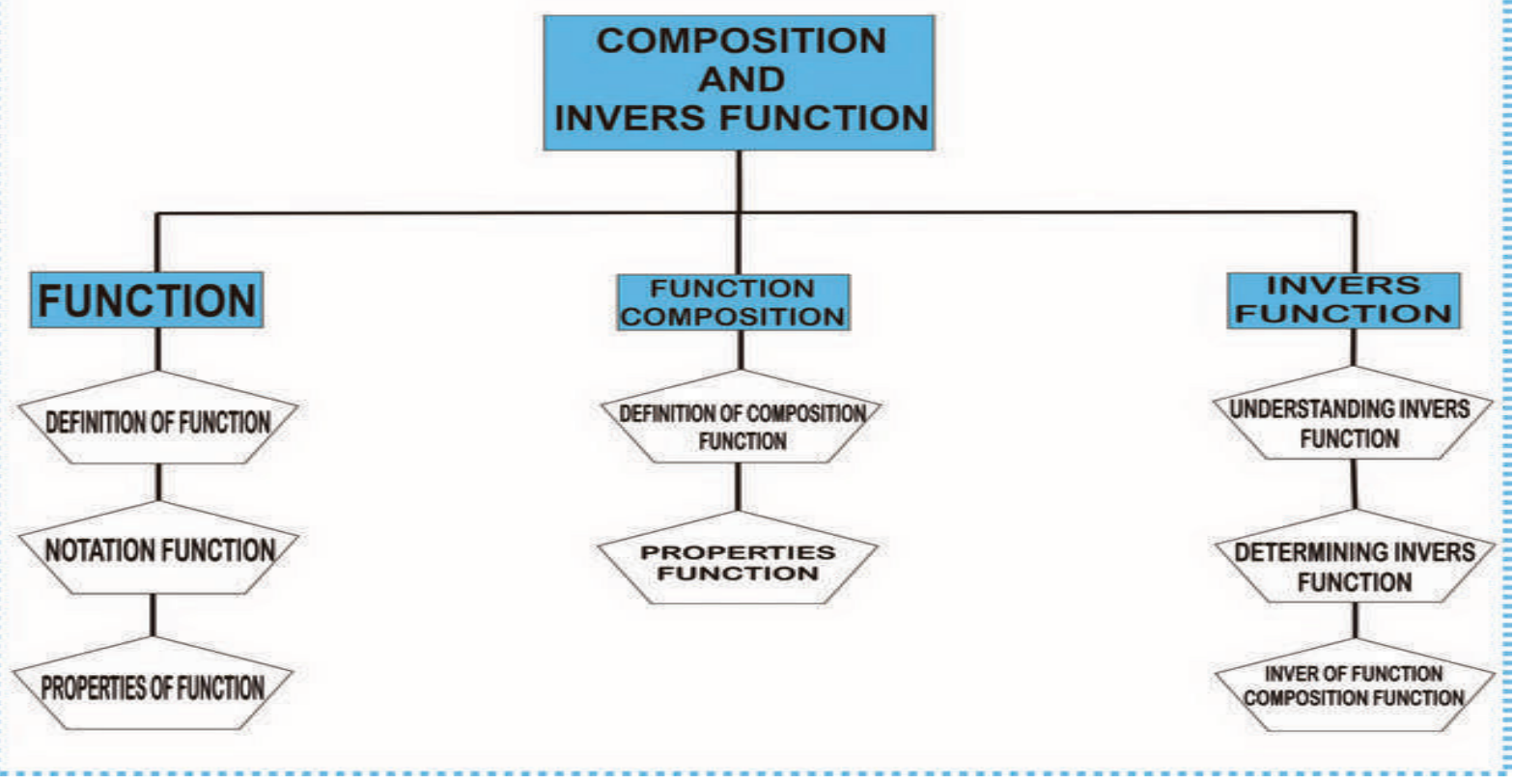

Figure 5. Concept Map Display

\section{Function}

\section{Definition of Function}

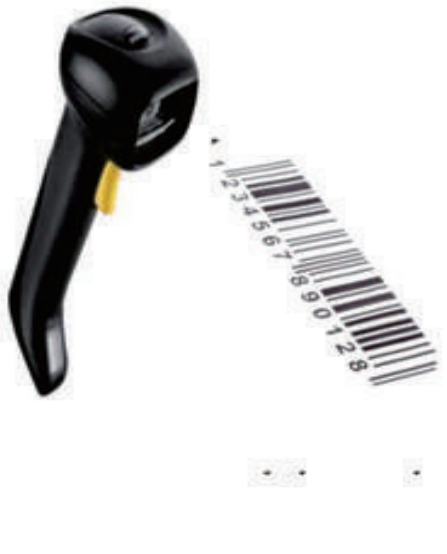

\subsubsection{Concept Maps}

The concept map in the Problem Based Learning (PBL) module contains topics to be studied in the module and shows the interrelationships between topics in the module. The following concept map designs have been created in
Before discussing the material about internal functions math, try to pay attention to the problem of function contained in everyday life. Of course is very much an example of a request function and supply function. If you shop at supermarkets, give it a try Observe all bekanjaan must have a label code respectively. By using a coded tool which is directed at the code label, cashier or you can know the prices of these items. Ever you wonder what process applies in coded? Does a certain function take place in it? To find out the answer from problem above, let us study this materi

Figure 6. Display Material

\section{Figure 5.}

\subsubsection{Core Section}

\subsubsection{Theory}

The material in the Problem Based Learning (PBL) 
module contains detailed explanations of the subjects that are delivered sequentially and systematically so that students easily master the learning material. In this module, several Learning Activities contain a description of the material, assignments, and summaries of each sub-chapter discussed. Next is the material design that has been made in Figure 6.

\subsubsection{Theory}

The task in this Problem Based Learning (PBL) module, contains exercises that need to be completed by students which are tasks to increase the competency students must have. Designing the following task has been made in Figure 7.

\section{THEORY}

\section{A. PROBLEM ESSAY}

1. Given that the sets $V=\{r, s, t\}$ and $W=\{12,15,17,19\}$. The function is. determined by $f=((r, 12),(s, 15),(t, 17))$.

a) Write that the inverse $f$ is $g: W \circ V$ as the set of pairs sequentially.

b) Show $f$ and $g$ with the arrow diagram.

c) Is the inverse f, i.e. g, a function? Explain your reasons!

2. Based on the image below which is a graph of the functions $f(x)$ and $g(x)$

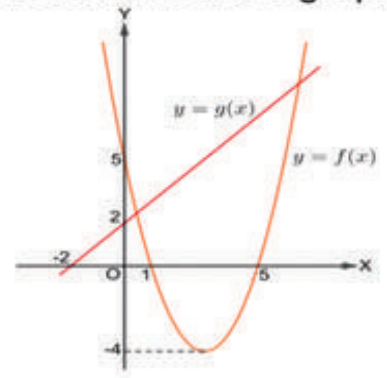

Determine the composition of the function $(f \circ g)(3)$ from the graph of the function is

3. To print $x$ copies of newspapers a day, a printing machine is required. In fact, if you use $x$ units of printing machines, the daily maintenance costs that: must be spent are machine maintenance today of IDR $50,000.00$, so many: copies of the printed newspaper are

4. If it is known that $(x)=5 x-7$ and the composition of the function ( $g \circ f)(x)$ $=4 x+8$, then is it true that $(x)=-x+7$ ? Show the truth / error of the statemen above and then provide a conclusion 


\subsubsection{Closing Section}

\subsubsection{Summary}

\section{Summary}

1. The relation of set $A$ to association $B$ is the installation or correspondence between member $A$ and member $B$

2. A function of set $A$ set $B$ is a relation that pairs each member of set $A$ with exactly one member of set $B$

3. The conditions for a function are as follows:

a) Each member A must be completely paired

b) Each member $A$ is paired exactly one with member $B$

4.f: $x$ o $y$ (read: $f$ means $x$ to $y$ ) $y$ is called the $x$ image by the function $f$ and is represented by $f(x)$

5. The nature of a special function is as follows:
a) One-to-one (injective) function
b) Function on (subjective)
c) One-to-one and on (wise) functions
d) Identity function
e) Constant function

6. The function $f(x)=g(x)$ is the composition of the functions $f$ and $g$, so that $f(x)$ is called the composition function

7. The properties of the composition of the function, for example, determine the rules for the function $f$, the function $g$ and the function $h$ of $R$

a) The composition operation is generally non-commutative meaning ( $f \circ$ $g)=(g \circ f)$

b) In the composition of the function the associative nature applies, namely $(f \circ g) \circ h=f \circ(g \circ h)$

c) Let I be the function I $(x)=x$ and satisfy $f \circ I=I$ of $=f$, then $I$ is the identity function

8. A function $f$ : $A, B$ has an inverse function $f-1$ : $B, A$ if $f$ is an independent function or the sets $A$ and $B$ correspond one to one

Figure 8. Summary Display

This summary in the Problem Based Learning (PBL) module examines the main points in the module discussed. The following summary design was created in Figure 8 . 


\subsubsection{Glossaries}

The glossary in the Problem Based Learning (PBL) module contains the concept definitions discussed in the module and summarized so students can easily understand and remember them. The following is a glossary design that was created in Figure 9.

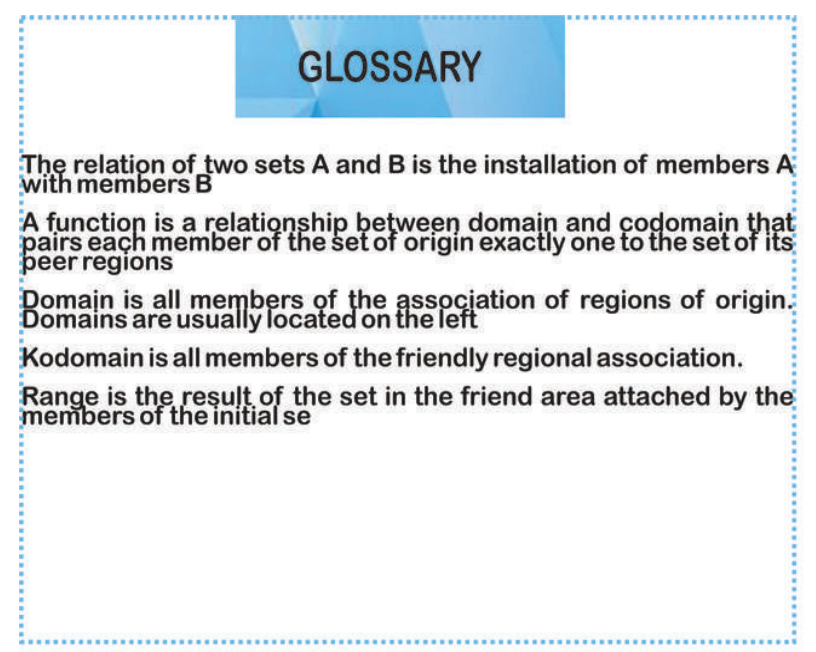

Figure 9. Glossary Display

\subsubsection{Reference}

This reference in this Problem Based Learning (PBL) module, contains sources of information about the contents of the module. The following reference designs have been created in Figure 10.

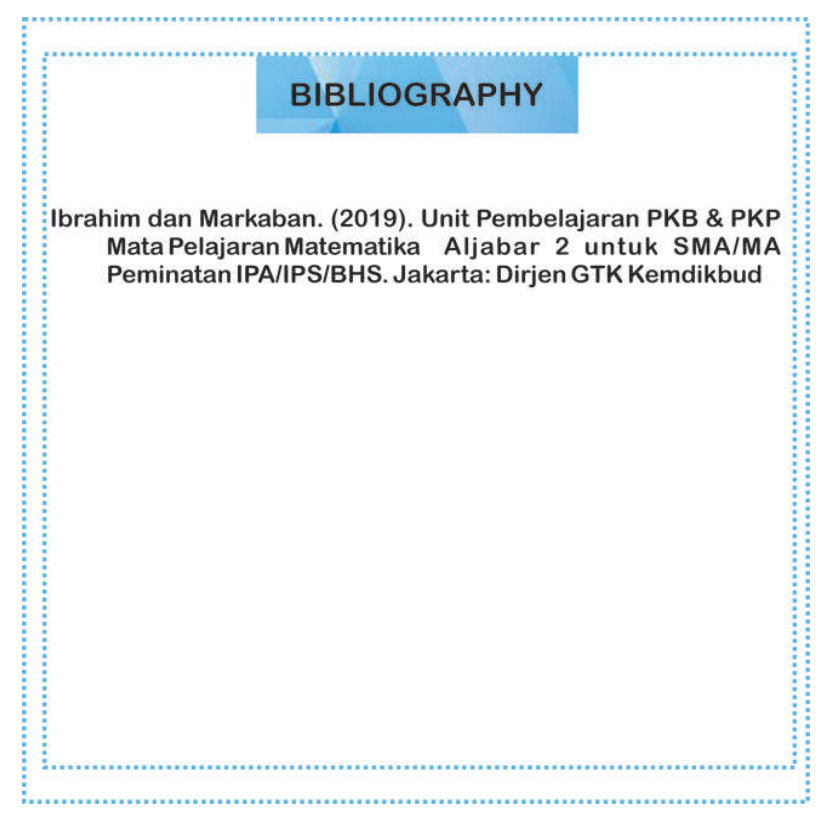

Figure 10. Display Bibliography

Further research can be continued at the development, implementation, and evaluation stages to produce products in the form of e modules that are valid, practical, and effective. Development contains module preparation activities referring to the module design that has been made. At this stage of development, the module is also validated by media experts and material experts. This development stage aims to produce a valid module. Implementation contains activities using modules to obtain feedback from students on the developed modules. At this implementation stage, students' responses to the module were collected through a questionnaire. This implementation stage aims to produce a practical module. Evaluation contains activities to assess students' mathematical communication skills after students use the module. At this evaluation stage, the module is revised so that the objectives of module development can be achieved. This evaluation stage aims to measure the achievement of the module development objectives.

\section{Conclusion}

This research resulted in the design of module Problem Based Learning (PBL). In the analysis phase, researchers grouped the analysis into four types, namely: curriculum analysis, material, student characteristics, and learning achievement. In curriculum analysis, researchers found that the curriculum used was the 2013 curriculum following the government. In the analysis of the material, the researcher found that students had difficulties because sentences or language used formal mathematics that was difficult to understand for students. In analyzing students' characteristics, reseachers found that students had difficulty working on problems because students could not understand the material very well. Whereas in the analysis of learning achievement, the authors found that the majority of students' mathematics test scores had not yet reached the individual Minimum Completion Criteria of 70. At the design stage, the reseachers designed three outlines, namely: the opening part, the core part, and the closing part. The opening part consists of a cover, introduction, module description, list of competency objectives, concept maps, table of contents, and preliminary tests. The core part consists of an introduction, material, and assignments. The concluding part consists of the final test, summary, and glossary. Modules designed have advantages. Modules are designed to improve mathematical communication skills in the subject matter because each indicator of mathematical ability is included in the questions in the module. Also, the module is designed following the Problem Based Learning (PBL) approach.

\section{Acknowledgements}

Our gratitude goes to Mr. Fachrul Rozi S.Pd as a mathematics teacher in class XI Vocational High School in Kulon Progo who has helped conduct research and semester 1 (one) Mathematics class XI Vocational High 
School students in the academic year 2019-2020.

\section{REFERENCES}

[1] Surya, E., Syahpurta, E., and Juniati, N., "Effect of Problem Based Learning Toward Mathematical Communication Ability and Self-Regulated Learning," Journal of Education and Practice, vol. 9, no.6, pp. 14-23, 2018.

[2] Ahmad and Jazuli, A., "Jigsaw Type of Cooperative Learning as a Means of Improving High School-Students' Mathematical Communication Ability," International Journal for Educational Studies, vol.1, no.2, pp. 207-2018, 2009.

[3] Rahmi, S., Nadia, R., Hasibah, B., and Hidayat, W., "The Relation Between Self-Efficacy Toward Math with the Math Communication Competence," Journal of Mathematics Education, vol.6, no.2, pp. 177-182, 2017.

[4] Lim, C.S. and Chew, C.M., "Mathematical Communication in Malaysian Bilingual Classrooms," in 3rd APEC-Tsukuba International Conference: Innovation of classroom teaching and learning through lesson study - focusing on mathematical communication, pp. 1-7, 2007.

[5] Sundayana, R., Herman, T., Dahlan, J.A., and Prahmana, R.C.I., "Using ASSURE learning design to develop students' mathematical communication ability," World Transactions on Engineering and Technology Education, vol.15, no.3, pp. 245-249, 2017.

[6] Nursolekah, S., and Suparman, "Design of Mathematics Learning Module Based on Problem Based Learning to Improve Critical Thinking Ability Students," International Journal of Scientific \& Technology Research, vol.8, no.12, pp. 2608-2616, 2019.

[7] Organisation for Economic Co-Operation and Development, Programme for International Student Assessment (PISA) Results From Pisa , pp. 1-10, 2018.

[8] Organisation for Economic Co-Operation and Development, Measuring Student Knowledge and Skills, OECD Publications Service, 1999.

[9] Atika, N., Roza, Y., and Murni, A., "Development of Learning Tools by Application of Problem Based Learning Models to Improve Mathematical Communication Capabilities of Sequence and Series Materials," Journal of Educational Sciences, Vol.4, No. 1, 62-72, 2020.

[10] Rahmantiwi, W.B., and Rosnawati, R., "The Effect of Problem Based Learning (PBL) Toward Mathematics Communication Ability and Curiosity," In IOP Conf. Series: Journal of Physics, pp. 1-6, 2018.

[11] Sitopu, F., "Development of Learning Devices Based on Problem Based Learning Model to Improve Mathematical Communication Skills," in 4th Annual International Seminar on Transformative Education and Educational Leadership (AISTEEL), pp. 539-542, 2019.
[12] Selçuk, G.S., "The effects of problem-based learning on pre-service teachers' achievement, approaches and attitudes towards learning physics," International Journal of the Physical Sciences, vol.5, no.6, pp. 711-723, 2010.

[13] Akma, T., and Suparman, "The Design of Student Worksheet Problem based Learning to Improve Problem Solving Ability of the Eighth-Grade Students Junior High School in Indonesia," International Journal of Engineering \& Technology, vol.7, no.4, pp. 11-15, 2018.

[14] Masdalipa, Harahap, M.B., and Derlina, "The Effect of Problem-Based Learning Assisted Concept Map to Problem-Solving Ability and Critical Thinking Ability," Journal of Education and Practice, vol.8, no.19, pp. 60-65, 2017.

[15] Simamora, R.E., Sidabutar, D.R., and Surya, E., "Improving Learning Activity and Students' Problem Solving Skill through Problem Based Learning (PBL) in Junior High School," International Journal of Sciences: Basic and Applied Research (IJSBAR), vol.33, no. 2, pp. 321-331, 2017.

[16] Saragih, S. and Habeahan, W.L., "The Improving of Problem Solving Ability and Students' Creativity Mathematical by Using Problem Based Learning in SMP Negeri 2 Siantar," Journal of Education and Practice, vol.5, no.35, pp. 123-133, 2014

[17] Ahmad, R.A., and Bayat, S., "Collaborative problem-based learning in mathematics: A cognitive load perspective," in 4th International Conference of Cognitive Science, pp. 344$350,2012$.

[18] Fajarini, A., Soetjipto, B.E., and Hanurawan, F., "Developing A Social Studies Module by Using Problem Based Learning (PBL) With Scaffolding for the Seventh Grade Students in A Junior High School in Malang, Indonesia," IOSR Journal of Research \& Method in Education (IOSR-JRME), vol.6, no. 1, pp. 62-69, 2016.

[19] Zulyadaini, A., "Development of Students' Worksheet Based on Contextual Teaching and Learning," IOSR Journal of Mathematics, vol.13, no.1, pp. 30-38, 2017.

[20] Harahap, L.W., and Surya, E., "Development of Learning Media in Mathematics for Students with Special Needs," International Journal of Sciences: Basic and Applied Research, vol. 33, no.3, pp. 1-12, 2017.

[21] Wahyuaji, N.R., and Suparman, "Development of STEM Integrated E-Learning Design to Improve Student's Creative Thinking Capabilities," International Journal of Scientific \& Technology Research, vol.8, no. 10, pp. 1164-1168, 2019.

[22] Nuari, L.F. and Suparman, "Designing Worksheets for the Mentally Retarded Student in Multiplication Operations," International Journal of Scientific \& Technology Research, Vol.8, No.10, 3579-3584, 2019.

[23] Fitri, N.L., and Suparman, "Designing Worksheet Using the Context of Sugarcane," International Journal of Scientific \& Technology Research, vol.8, no.11, pp. 3669-3672, 2019.

[24] Welty, G., "The Design Phrase of the ADDIE Model," Journal of GXP Compliance, vol.11, no.4, pp. 40-48, 2007. 